\title{
XAFS を用いた固体酸化物形燃料電池の電極反応解析
}

\author{
雨 澤 浩 史 \\ 東北大学多元物質科学研究所 凿 980-8577 宮城県仙台市青葉区片平 2 丁目 1-1 \\ （2015 年 11 月 23 日受付；2015 年 12 月 11 日掲載決定） \\ Analysis of Electrode Reaction in Solid Oxide Fuel Cells by Using XAFS \\ Koji AmeZawa \\ Institute of Multidisciplinary Research for Advanced Materials, Tohoku University, \\ 2-1-1 Katahira, Aoba-ku, Sendai, Miyagi 980-8577
}

(Received November 23, 2015 ; Accepted December 11, 2015)

\begin{abstract}
Solid oxide fuel cell (SOFC), which is one type of fuel cells having a potential of high energy conversion efficiency, has been commercialized, for instance since 2011 in Japan. For further wide-spread commercialization of SOFC, improvements of the cell performance are highly required. Since electrode performance often limits the cell performance, it is important to improve the electrode kinetics based on the knowledge of physical/chemical states of the electrodes. However, SOFC operates at high temperature under specific atmospheric condition. Thus it is not so easy to directly observe the states of the electrodes under operation. In this paper, our experimental trials of direct observation of SOFC electrodes by means of X-ray absorption fine structure (XAFS) are reviewed.
\end{abstract}

KEYWORDS : solid oxide fuel cell, electrode, XAFS, hard X-ray, soft X-ray

\section{1.は じめに}

燃料電池は, 燃料のもつ化学エネルギーを直接電気エ ネルギーに変換することができるため, 高効率のエネル ギー変換デバイスとして期待されている。燃料電池に は, 使用する電解質の種類に応じて作動温度の異なるい くつかのタイプがある。現在, 最も広く普及しているの は, プロトン導電性の固体高分子膜を用いる固体高分 子形燃料電池 (Polymer Electrolyte Fuel Cell, PEFC) である。一方, 安定化ジルコニア（たとえば, $\left.\left(\mathrm{Y}_{2} \mathrm{O}_{3}\right)_{0.08}\left(\mathrm{ZrO}_{2}\right)_{0.92}, 8 \mathrm{YSZ}\right)$ に代表される酸化物イオン 導電体など，イオン伝導性セラミックスを電解質に用い る固体酸化物形燃料電池（Solid Oxide Fuel Cell, SOFC） も, 次世代燃料電池として注目されている。SOFCは, その高い作動温度 $\left(700-1000^{\circ} \mathrm{C}\right)$ ゆえに, 燃料電池の中 でもエネルギー変換効率が高く, また, 多様な燃料が使 用可能である，高品位な排熱利用ができる，など，優れ

E-mail : amezawa@tagen.tohoku.ac.jp
た特徵を有している。

我が国では 2011 年より既にSOFC の販売が開始され ているが, 今後 SOFC を本格的に普及させていくため には, 現状よりもさらなる高性能化, 高効率化, 高信頼 性化, 長寿命化, 低コスト化を図る必要がある。これら を達成するために解決すべき課題には様々なものが考え られるが, なかでも, 電池特性を左右する電極, 特に酸 素ガスの電気化学還元反応を伴う空気極の性能向上は, 最も大きな課題の一つといえよう。

SOFC の空気極には, 一般的に, $(\mathrm{La}, \mathrm{Sr}) \mathrm{CoO}_{3-\delta}$ や $(\mathrm{La}, \mathrm{Sr})(\mathrm{Co}, \mathrm{Fe}) \mathrm{O}_{3-\delta}$ に代表される酸化物イオン一電子混 合導電性材料が用いられる。この場合, 電極反応は, 電 極（イオン一電子混合導電体）/ガス（反応ガス, 生成ガ ス）から構成される二相界面において進行する。実際の SOFC 電極としては, 反応が起こる表面を増やし, か つ, 反応ガスあるいは生成ガスが内部を容易に拡散し得 るよう, 電極材料 (もしくは電極材料と電解質材料のコ ンポジット）を多孔体にして用いるのが一般的である。 したがって, 高性能電極を開発するためには, 二相界面 
における電極反応素過程（ガス拡散，ガスの吸着・解 離，イオン拡散，電荷移動など）や反応サイトおよび反 応量の分布を理解した上で，トータルの電極反応を円滑 に進行させ得るよう, 電極材料・構造を選択・設計する ことが重要である。

SOFC における電極反応を調べる際，最も多用される のは直流分極や交流インピーダンスといった電気化学的 手法である。これらの手法は，電極反応に関する有益な 情報を多く与えてくれるが，得られる信号は電圧印可に 伴う電流信号あるいは逆に限られるため，これらのみか ら電極や電解質の物理/化学状態を直接知るのは困難で ある。電極や電解質の状態を直接評価するには，電気化 学的手法と分光学的手法の併用が有効である。このよう な考えのもと, 筆者等の研究グループでは, SOFC の電 極や電解質の状態を, 実際のデバイス作動環境下, もし くはそれに近い環境下において評価することのできる 「高温・雾囲気制御・電気化学オペランド分光測定法」 の開発を行ってきた。特に, 高輝度, 高指向性の X 線 を得ることのできる大型放射光施設を利用することで, 新たなオペランド分光測定技術の確立に努めてきた。本 稿では, X 線吸収微細構造 (X-ray Absorption Fine Structure, XAFS）測定を用いて我々が取り組んでいる SOFC 電極の反応解析の研究の数例を紹介する。

\section{SOFC 空気極の硬 X 線 XAFS 測定}

\section{1 硬 $\mathrm{X}$ 線オペランド XAFS 測定}

$\mathrm{X}$ 線は 0.01-0.1 nm 程度の波長をもつ電磁波であり, 一般に物質との相互作用は小さい。しかし，含まれる元 素の内殼電子を非占有軌道以上に励起するに十分なエネ ルギーをもった X 線を物質に入射すると，入射 X 線の 一部が物質に吸収される。吸収が生じるX $\mathrm{X}$ 線エネルギ 一は, 含まれる元素の種類, 化学状態, 構造・配位状態 などに依存する。本稿で紹介する研究に用いられる XAFS 測定は，このX 線吸収現象を観測することによ り，物質の電子構造や局所構造を分析評価する手法であ る。XAFS 測定は, 特定の元素に関する情報が選択的 に, かつ比較的高感度で得られる, 原理的には非破壊・ 非接触の分析手法である。特に，比較的エネルギーの高 い X 線（約 $4 \mathrm{keV}$ 以上，硬 X 線）は，物質に対する透 過能が高いため, 軽元素で構成される物質（ガス, 溶 媒，有機・高分子材料など）を容易に透過する。さら に，硬 X 線を用いた各種測定は，温度や雲囲気に対す る制約も少なく，極低温から高温，高真空から高圧条件 まで対応可能である。そのため, 硬 X 線を用いた XAFS 測定は，特殊環境下で作動するデバイスのオペラ ンド分析に広く用いられている1)。
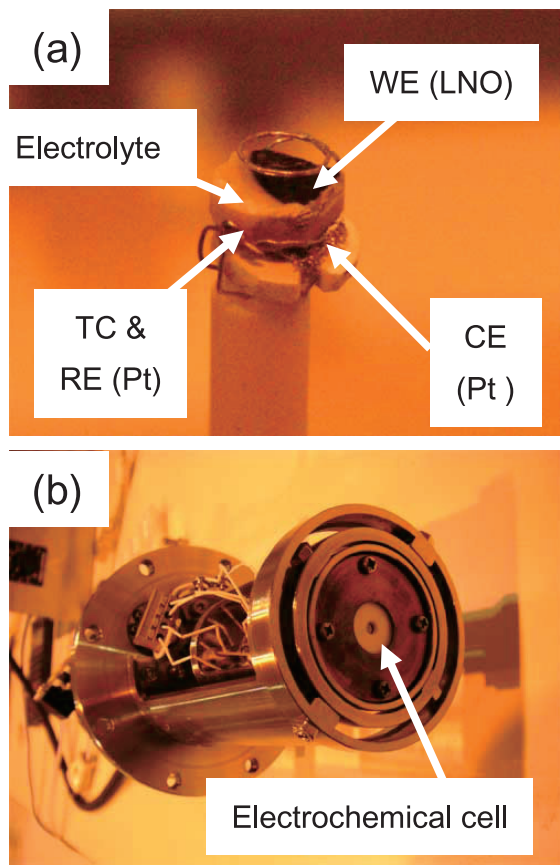

Fig. 1. (color online). Equipment for high-temperature electrochemical operando XAFS measurements: (a) three terminal electrochemical cell and (b) sample holder.

しかし, 本稿で対象とする固体酸化物形燃料電池は, 高温 $\left(700-1000^{\circ} \mathrm{C}\right.$ 程度), 制御ガス䨌团気 $\left(\mathrm{O}_{2}, \mathrm{H}_{2}\right.$, $\mathrm{H}_{2} \mathrm{O}$ 分圧など), 通電といった非常に特殊な条件下で作 動する。そのため, 前述のような特徵をもつ硬 X 線 XAFS 測定ですら，オペランド測定への適用例はほとん どなかった。このような状況に対し，筆者等は，Fig. 1 に示す高温電気化学 XAFS 測定用試料ホルダーを開発 した ${ }^{2)}$ 。このホルダーでは, 先端に 3 電極式の固体電気 化学セルを搭載でき，このセル周囲にカンタル線ヒー夕 一を配置することで，七ル温度を $1000^{\circ} \mathrm{C}$ まで昇温でき るようにした。電極リード線, 熱電対, ヒーター線は, 試料ホルダー後部から取り出せる構造とした。セル周囲 の雲囲気（ガス分圧）は，X線入・出射用のカプトン膜 製空を配した筒で試料ホルダーを覆い，ホルダー内に任 意のガスを一定流量でフローすることにより, 調整可能 とした。X 線吸収量の測定は蛍光収量法により行った。 次節では，この装置を用いてオペランド計測された薄膜 モデル SOFC 空気極の結果を紹介する。

\section{2 薄膜モデル空気極を用いた電極反応解析}

本節では, SOFC 空気極を模擬した緻密薄膜電極の オペランドXAFS 測定を通し, 電極反応メカニズム について検討した例を紹介する舟名。電解質 $\left(\mathrm{Y}_{2} \mathrm{O}_{3}\right)_{0.08}\left(\mathrm{ZrO}_{2}\right)_{0.92}(8 \mathrm{YSZ})$ 上に作製した $\mathrm{La}_{2} \mathrm{NiO}_{4+\delta}$ (LNO) 薄膜（150 nm 厚）電極を用いて得られた $\mathrm{Ni} K$ 

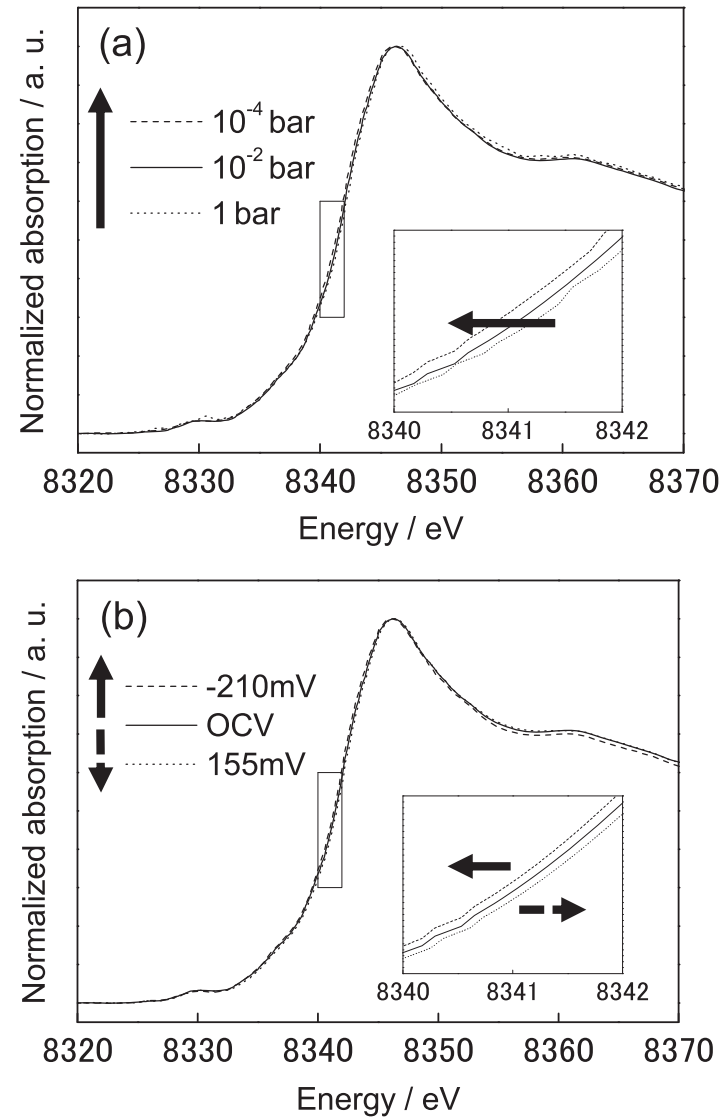

Fig. 2. Ni $K$-edge XAFS spectra of the $\mathrm{La}_{2} \mathrm{NiO}_{4+\delta}$ dense thin film electrode on the $\left(\mathrm{ZrO}_{2}\right)_{0.92}\left(\mathrm{Y}_{2} \mathrm{O}_{3}\right)_{0.08}$ electrolyte at $700^{\circ} \mathrm{C}$ (a) under open circuit and $p\left(\mathrm{O}_{2}\right)=10^{-4}-1 \mathrm{bar}$, and (b) under cathodic bias of $-210-+155 \mathrm{mV}$ and $p\left(\mathrm{O}_{2}\right)=10^{-2}$ bar.

端 XAFS スペクトルをFig. 2 に示す。この実験は SPring-8の BL01B1において行われた。Fig. 2(a) は, 温度 : $700^{\circ} \mathrm{C}$ の開回路状態において, 䨌囲気中の $p\left(\mathrm{O}_{2}\right)$ を変化させた際に得られたスペクトルである。この図に 示されるとおり, Ni $K$ 吸収端は, 雲囲気中の $p\left(\mathrm{O}_{2}\right)$ の増 加に伴い, わずかではあるが, 高エネルギー側にシフト した。LNOは, 格子間酸素生成による顕著な酸素不定 比性を示すことが知られており, この過剩酸素により酸 化物イオン伝導が発現する。過剩酸素量 $\delta$ は, 材料が嚗 される酸素ポテンシャル（酸素分圧 $p\left(\mathrm{O}_{2}\right)$ ) に応じて増 減する。Fig. 2 (a) で観測された吸収端エネルギーの変 化は, $p\left(\mathrm{O}_{2}\right)$ 変化により, LNO 中の酸素不定比量が変化 し, それに伴って $\mathrm{Ni}$ イオンの形式価数が増加したこと を反映していると解釈される。本実験での $p\left(\mathrm{O}_{2}\right)$ 変化 (1-10 ${ }^{-4}$ bar) に対し, LNOに打ける酸素不定比量 $\delta$ の 変化は多くても 0.05 程度, $\mathrm{Ni}$ イオンの形式価数変化に すると 0.1 程度と見積もられる。Fig. 2 (a) の結果は, この程度のわずかなカチオン価数の変化であっても

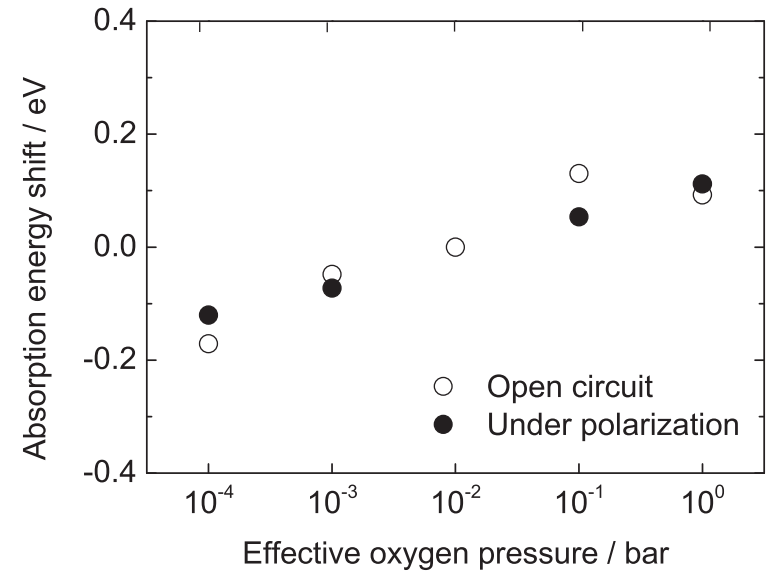

Fig. 3. Relation between effective oxygen pressure and energy shift of Ni $K$-edge XAFS spectra of the $\mathrm{La}_{2} \mathrm{NiO}_{4+\delta}$ dense thin film electrode at $700^{\circ} \mathrm{C}$.

XAFS 測定により検出できることを示している。

Fig. 2 (b) に, 温度 $: 700^{\circ} \mathrm{C}, p\left(\mathrm{O}_{2}\right): 10^{-2}$ bar に保ち ながら, LNO 緻密薄膜電極に通電した際に測定された Ni $K$ 吸収端 XAFS スペクトルを示す。温度, $p\left(\mathrm{O}_{2}\right)$ が一 定であるにもかかわらず，吸収端エネルギーは，カソー ド分極（マイナスの電圧を印加）させると低エネルギー 側に，アノード分極（プラスの電圧を印加）させると高 エネルギー側にシフトした。この結果は, 電圧の印加に より, 電極中の酸素の不定比量, カチオンの形式価数が 変化すること, 言い換えると, 電極が曝される酸素ポテ ンシャルが変化することを示している。

Fig. 2 (a)，（b）のスペクトルで観測された吸収端エ ネルギーのシフト量を Fig. 3 に示す。この図では, $10^{-2}$ bar, 開回路時のスペクトルにおける吸収端エネルギー を基準とした。また, 電圧印加時の実効酸素分圧 $p^{\text {eff }}\left(\mathrm{O}_{2}\right)$ （酸素ポテンシャル $\left.\mu_{0}=1 / 2 \ln p^{\text {eff }}\left(\mathrm{O}_{2}\right)\right)$ は, 電 極に加えられた過電圧 $\Delta \eta($ 電極に加えられた電圧から, 電解質抵抗などオーミック抵抗による電圧ロスを差し引 いた量）と気相の酸素分圧 $p\left(\mathrm{O}_{2}\right)$ により, 次式に従って 求めた。

$$
p^{\text {eff }}\left(\mathrm{O}_{2}\right)=p\left(\mathrm{O}_{2}\right) \exp (4 F \Delta \eta / R T)
$$

なお， $F, R$ はそれぞれ, ファラデー定数, ガス定数で ある。Fig. 3 より, 電圧印可時の吸収端シフト量は, 開 回路時のそれとよく一致することがわかった。この結果 は, 電圧印可に伴う実効酸素分圧変化は，（1）式で表さ れると解釉できることを示している。今回測定に使用し た LNO 薄膜の厚さは, 硬 X 線が十分に透過できる 150 $\mathrm{nm}$ であることから, 分極に伴う実効酸素分圧変化は, 膜厚方向に平均した電極状態を観測していることにな る。すなわち, Fig. 3 の結果は, 通電時の電極近傍での 


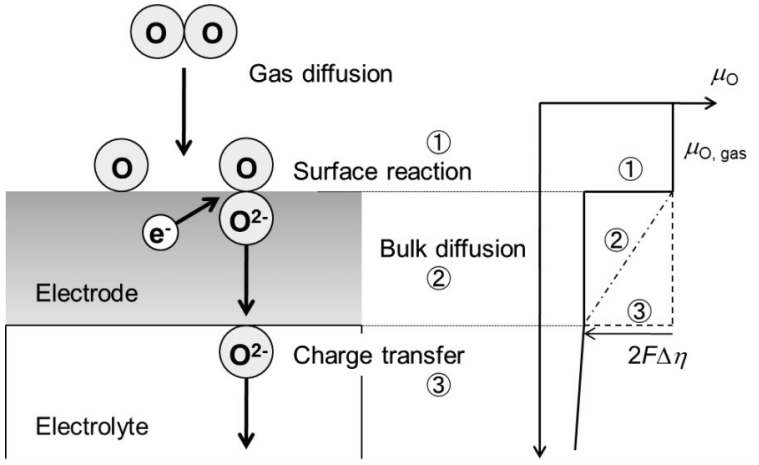

Fig. 4. Schematic illustration of electrochemical oxygen reduction reaction and oxygen chemical potential distribution at an SOFC mixed-conducting cathode.

酸素ポテンシャル変化の様子が電極表面で生じており, 電極の内部では酸素ポテンシャルがほぼ一定と見做せる ことを示している。SOFC 空気極に打ける酸素の電気化 学還元反応は, トータルでは,

$1 / 4 \mathrm{O}_{2}+\mathrm{e}^{-} \rightarrow 1 / 2 \mathrm{O}^{2-}$

と記述することができるが，より詳細にみると，Fig. 4 に示されるとおり, 酸素ガスの拡散, 酸素ガスの電極表 面への吸着・解離（表面反応）, 電極内部あるいは表面 での酸素イオンの拡散, 電極/電解質界面での電荷移動 など, いくつかの素過程からなると考えられている。電 圧印可に伴う酸素ポテンシャル変化が電極表面で生じて いるということは，8YSZ 上の LNO 薄膜電極における 酸素の電気化学還元反応が表面反応律速であることを表 している。このように，オペランドXAFS 測定を用い ることにより，従来の手法では評価が困難であった電池 作動時の SOFC 材料の化学状態を直接明らかにするこ とができ，これにより電極反応メカニズムに関する情報 を得ることが可能となる。

\section{3 さらに高度な硬 $\mathrm{X}$ 線オペランド XAFS 測定}

諸言で述べたとおり, 実際の SOFCでは，一般に， 電極材料の微粒子を多孔体にした多孔体電極が用いられ る。2.2 節の測定で用いた薄膜モデル電極では, 電極反 応が進行する二相界面は電極薄膜表面に限定され，また 反応量も部位に依らず一様と見做すことができる。一 方, 実際の多孔体電極では, 二相界面は 3 次元的に広が って存在する。しかも，すべての二相界面において電気 化学反応が一様に起こるわけではない。そのため, 電極 反応サイトの分布ならびに個々のサイトにおける反応量 を知ることも，高性能電極を開発する上では重要であ る。このような SOFC 電極における反応分布の評価も, たとえばマイクロ X 線ビームを用いた位置分解 XAFS 測定を行えば可能となる。実際, 筆者等の研究グループ
では，マイクロX 線ビームを使用することのできる SPring-8 の BL37XU に押いて, オペランドの硬X 線マ イクロXAFS 測定を行い，たとえば $\mathrm{La}_{0.6} \mathrm{Sr}_{0.4} \mathrm{CoO}_{3-\delta}$ 多 孔体電極における反応分布の直接評価にも成功してい る。紙面の都合上，本稿では詳細には触れないが，興味 のある方は別報を参考されたい ${ }^{4,5)}$ 。

\section{SOFC 空気極の軟 X 線 XAFS 測定}

\section{1 軟 $\mathrm{X}$ 線オペランド XAFS 測定}

SOFC 空気極には， $3 \mathrm{~d}$ 遷移金属 $(\mathrm{Mn}, \mathrm{Fe}, \mathrm{Co}, \mathrm{Ni}$ な ど）を含む複合酸化物が用いられることが多い。前章で は, 硬 X 線 XAFS 測定を SOFC 電極反応解析に適用し た例を示した。しかし，硬 $\mathrm{X}$ 線を用いた $3 \mathrm{~d}$ 遷移金属 $K$ 吸収端の XAFS 測定では, 主として $3 \mathrm{~d}$ 遷移金属の $1 \mathrm{~s}$ 軌 道から $4 \mathrm{p}$ 軌道への励起に伴う X 線吸収現象を観測して いるため, 電気的, 電気化学的性質に深く関連する酸化 物のフェルミレベル近傍の電子状態（3d 遷移金属 $3 \mathrm{~d}$ 軌 道，酸素 $2 \mathrm{p}$ 軌道）を直接観測しているわけではない。 $3 \mathrm{~d}$ 遷移金属の $3 \mathrm{~d}$ 軌道, 酸素 $2 \mathrm{p}$ 軌道の電子状態を評価 するには, $3 \mathrm{~d}$ 遷移金属 $L_{\mathrm{II}}, L_{\mathrm{III}}$ 吸収端, $\mathrm{O} K$ 吸収端での XAFS 測定が有効である。しかし，これらの吸収端は, 硬 X 線よりもエネルギーの低い軟 X 線領域（500～1000 $\mathrm{eV})$ にある。軟 X 線は, 硬 X 線とは異なり, 酸素, 窒 素等のガスにも容易に吸収されてしまうため, 軟 X 線 XAFS 測定は高真空下で行われるのが一般的である。し かし, 温度, $p\left(\mathrm{O}_{2}\right)$ によって酸素不定比量が変化する酸 化物にとって，高真空下での測定は適切ではない。

このような現状を打破すべく，筆者等のグループは, $3 \mathrm{~d}$ 遷移金属酸化物の電子構造を高温, 制御雲囲気で評 価できる軟 X 線 XAFS 測定技術の開発を行ってきた。 $\mathrm{JASRI}$ ・為則等によって開発された大気圧環境下軟 X 線 分光用差動排気システム ${ }^{6}$ の試料室を, $\mathrm{Si}_{3} \mathrm{~N}_{4}$ 薄膜の空 で差動排気部（軟 X 線導入部）から隔離することによ り, 制御雲囲気下での軟 X 線 XAFS 測定が可能となっ た7,8)。試料雲囲気は, 試料室に任意のガス（たとえば, $p\left(\mathrm{O}_{2}\right)$ 制御の場合, $\mathrm{He}$ 希釈の $\mathrm{O}_{2}$ ガス) をフローするこ とで, 試料周囲の全圧を 1 bar に保ちつつ, 制御した。 オペランド測定は, 硬 X 線 XAFS 測定に用いたものと ほぼ同じ構造の三電極式セルを, 自作の小型電気炉に搭 載することにより行った。

高温・雾囲気制御型軟 X 線 XAFS 測定の有効性，適 用限界について検討した結果を以下に示す。Fig. 5 (a) には温度：室温, $p\left(\mathrm{O}_{2}\right): 10^{-1}-10^{-4}$ bar, Fig. 5（b）に は温度：室温 $-600^{\circ} \mathrm{C}, p\left(\mathrm{O}_{2}\right): 10^{-4} \mathrm{bar}$ の条件下で測定 された $\mathrm{LaCoO}_{3}$ の $\mathrm{Co}_{L_{\mathrm{II}}}, L_{\mathrm{III}}$ 吸収端 XAFS スペクトルを 示す。この害験は SPring-8の BL27SU において行われ 

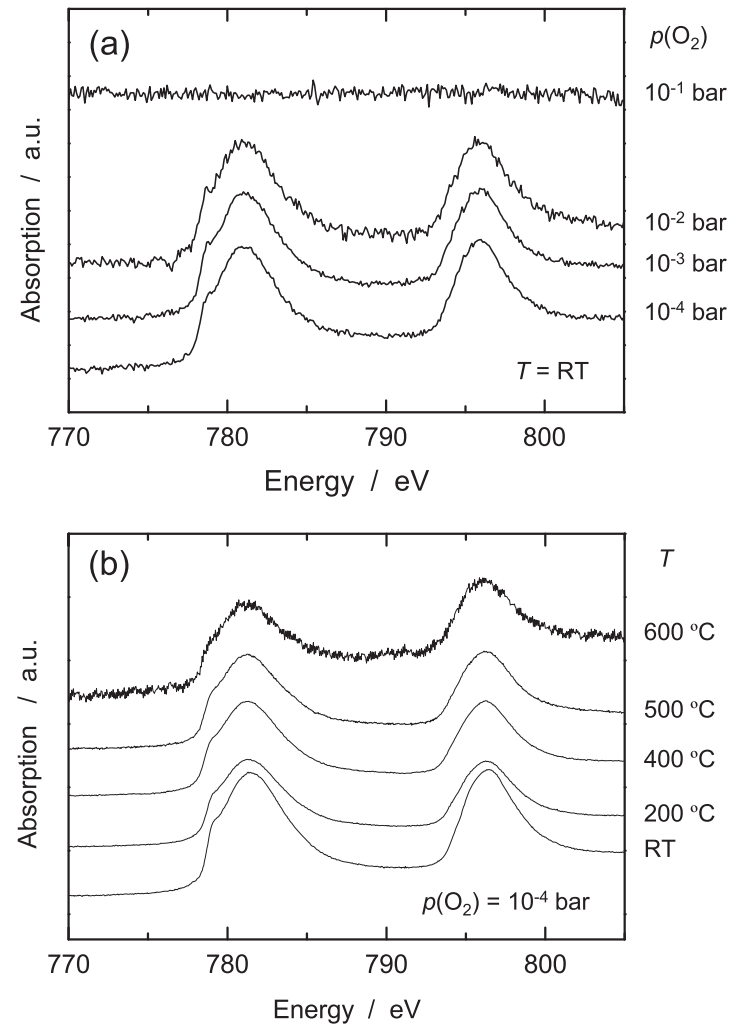

Fig. 5. Co $L_{\mathrm{II}}-$ and $L_{\mathrm{III}}$-edge XAFS spectra of $\mathrm{LaCoO}_{3}$ (a) under $p\left(\mathrm{O}_{2}\right)=10^{-1}-10^{-4}$ bar at room temperature and (b) under $p\left(\mathrm{O}_{2}\right)=10^{-4}$ bar at room temperature $-600^{\circ} \mathrm{C}$.

た。筆者等の開発したシステムにより, 大気圧環境下で あっても, $p\left(\mathrm{O}_{2}\right)$ や温度がある程度低ければ, 軟 $\mathrm{X}$ 線 XAFS スペクトルの取得が可能であることがわかる。一 方で, $p\left(\mathrm{O}_{2}\right)$ が $10^{-1}$ bar 以上あるいは温度が $600^{\circ} \mathrm{C}$ 以上 になると，雲囲気中の酸素ガスによるX 線の吸収ある いは電気炉からの輻射の影響により，少なくとも今回の セットアップでは, XAFS 測定は困難であった。

\section{2 薄膜モデル空気極を用いた電極反応解析}

3.1 節で紹介した軟 X 線オペランドXAFS 測定技術 を, 2.2 節で用いたものと同様の LNO 緻密薄膜電極の オペランド計測に適用した9)。温度: $500^{\circ} \mathrm{C}, p\left(\mathrm{O}_{2}\right)$ : $10^{-3}$ barにおいて, LNO 緻密膜電極をカソードあるいは アノード分極した際に観測された $\mathrm{Ni} L_{\mathrm{III}}$ 吸収端, $\mathrm{O} K$ 吸 収端 XAFS スペクトルを，Fig. 6 (a)，（b）にそれぞれ 示す。いずれも明瞭なスペクトルが観測されたことか ら，筆者等によって開発された技術を用いれば，完全な SOFC 作動条件（温度：700 $800^{\circ} \mathrm{C}$ 前後, $p\left(\mathrm{O}_{2}\right): 0.21$ bar）下とはいえないが，それにかなり近い条件下にお いて SOFC 材料の軟 X 線オペランドXAFS 測定が可能 であることがわかった。Fig. 6 (a) の Ni $L_{\text {III }}$ 吸収端スぺ クトルでは，電圧印可をしてもスペクトルに顕著な変化
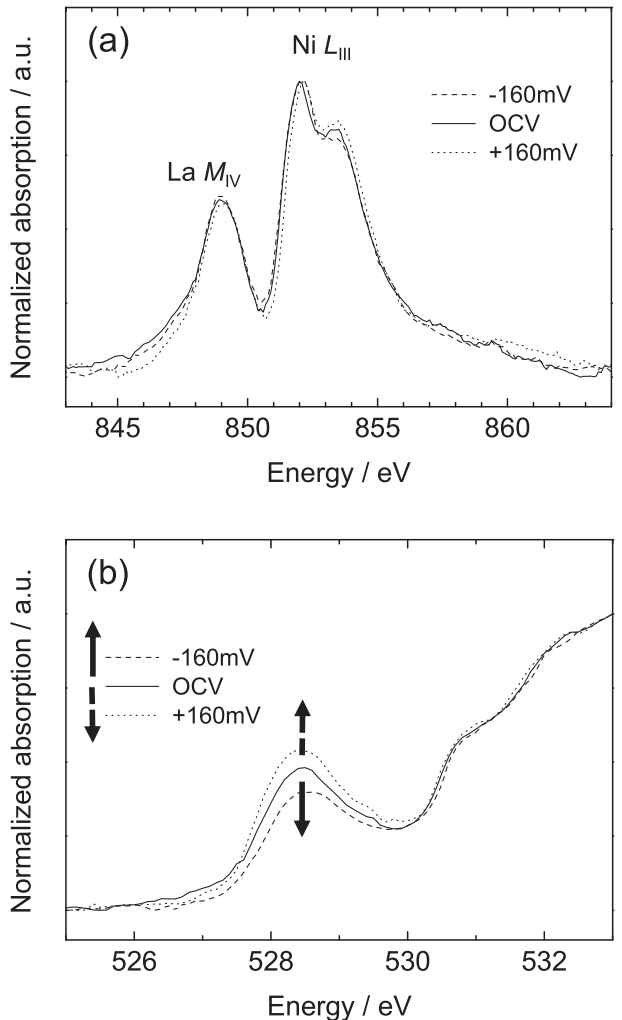

Fig. 6. (a) $\mathrm{Ni} L_{\mathrm{III}}$-edge and (b) $\mathrm{O} K$-edge XAFS spectra of the $\mathrm{La}_{2} \mathrm{NiO}_{4+\delta}$ dense thin film electrode on the $\left(\mathrm{ZrO}_{2}\right)_{0.92}\left(\mathrm{Y}_{2} \mathrm{O}_{3}\right)_{0.08}$ electrolyte under $p\left(\mathrm{O}_{2}\right)=10^{-3}$ bar and $-160-+160 \mathrm{mV}$ of cathodic bias at $700^{\circ} \mathrm{C}$.

は見られなかった。これに対し， $O K$ 吸収端スペクトル では，分極に伴い，Ni 3d 軌道との混成軌道に起因する と考えられる $528.5 \mathrm{eV}$ 付近のピークの強度が増減した。 3.2 節で述べたとおり, この結果は, カソードあるいは アノード分極に伴い, LNO 緻密膜電極の酸素不定比量 が減少あるいは増加することを示している。一般に, LNO のような $3 \mathrm{~d}$ 遷移金属酸化物の酸素不定比変化は, 含まれる $3 \mathrm{~d}$ 遷移金属イオンの価数の増減を引き起こす と解釈される。しかし，Fig.6（a）および（b）の結果 は, 酸素不定比量の増減, すなわち酸化物の酸化還元 が，3d 遷移金属イオンではなく, 酸化物イオンの酸化 還元によることを示している。軟 X 線オペランド測定 によるSOFC 電極の状態ならびに反応解析はまだまだ その端緒についたばかりであるが, Fig. 6 に示した結果 は, SOFC 電極で生じている変化を, 電子構造変化の観 点からより正確に把握できる可能性があることを示して いる。

\section{4. を め}

本稿では，筆者等が行ってきたオペランド測定による 
SOFC 電極の状態評価や反応解析の研究成果の一端を紹 介した。オペランド測定の導入は，これまで困難であっ た SOFC 材料の作動条件下における直接分析を可能と する。近年では, 大型放射光等への敷居が比較的低くな ったこともあり，本稿で紹介したXAFS 測定に代表さ れる, 量子ビームを利用したオペランド測定も以前に比 べて一般的になりつつある。また, 計測・制御機器の高 性能化も著しく, たとえば, 高位置分解あるいは高時間 分解測定, 二〜三次元測定, 極表面分析など, 測定手法 の高度化も進められている。もちろん, これまでも汎用 的に用いられている電気化学測定等の測定・分析手法が 有用であることはいうまでもない。しかし，これらの汎 用測定とオペランド分光測定を組み合わせることによ り, SOFC における反応やイオン輸送についての理解を 深められることが期待される。さらに, 本稿で紹介した 測定技術は, SOFC 材料のみならず, 高温, 制御雲囲気 下における酸化物の物性研究にも適用が可能であろう。 本稿がそのような研究に携わる読者諸氏の一助になった のであれば幸いである。

\section{謝辞}

本稿で紹介した研究は, 京都大学・内本喜晴教授, 折 笠有基助教, 東北大学. 川田達也教授, 八代圭司准教 授, 宇根本篤講師, 中村崇司助教, 高輝度光科学研究セ ンター・宇留賀朋哉博士, 谷田肇博士 (現京都大学),
寺田靖子博士, 新田清文博士, 為則雄祐博士（以上, 順 不同）はじめ, 多くの方々のご協力のもと実施されたも のである。ここに改めて謝意を表する。

\section{文献}

1) 太田俊明編: “X 線吸収分光法一XAFS とその応用 一”,アイピーシー (2002).

2) 雨澤浩史, 内本喜晴 : Electrochemistry 79, 720 (2011).

3) Y. Orikasa, T. Ina, K. Yamamoto, T. Nakano, A. Mineshige, K. Amezawa, T. Kawada, H. Tanida, T. Uruga and Y. Uchimoto: Electrochemistry 82, 897 (2014)

4) Y. Fujimaki, H. Watanabe, Y. Terada, T. Nakamura, K. Yashiro, S. Hashimoto, T. Kawada and K. Amezawa : Electrochem. Soc. Trans. 57, 1925 (2013).

5) K. Amezawa, Y. Fujimaki, T. Nakamura, K. DevelosBagarinao, K. Yamaji, K. Nitta, Y. Terada, F. Iguchi, K. Yashiro, H. Yugami and T. Kawada : Electrochem. Soc. Trans. 66, 129 (2015).

6) Y. Tamenori : J. Synchrotron Rad. 20, 419 (2013).

7) R. Oike, K. Amezawa, T. Nakamura, Y. Tamenori, K. Yashiro and T. Kawada: Solid State Ionics 262, 911 (2014).

8) R. Oike, K. Amezawa, T. Nakamura, Y. Tamenori, K. Yashiro and T. Kawada: Electrochem. Soc. Trans. 57, 2051 (2013).

9) 大池 諒, 為則雄祐, 藤巻義信, 中村崇司, 八代圭司, 川田達也, 雨澤浩史 : 2014 年電気化学会第 81 回大会 講演要旨集 (2014) 3C19. 